\title{
Pertumbuhan Lili (Lilium longiflorum) Pada Berbagai Komposisi Media Tanam dan Zat Pengatur Tumbuh Naphthalene Acetic Acid (NAA) pada Tahap Aklimatisasi
}

\section{Growth of Lilies (Lilium longiflorum) On Different Compositions of Plant Media and Growth Regulator of Naphthalene Acetic Acid (NAA) at the Acclimatization Stage}

\author{
Lulu Fatikhatul Maryamah ${ }^{1 *}$, Florentina Kusmiyati², Syaiful Anwar ${ }^{2}$ \\ ${ }^{1}$ Program Studi Agroteknologi, Departemen Pertanian, Fakultas Peternakan dan Pertanian \\ Universitas Diponegoro \\ ${ }^{2}$ Departemen Pertanian, Fakultas Peternakan dan Pertanian, Universitas Diponegoro \\ *Email : lulumaryamah23@gmail.com
}

Diterima 9 April 2019 / Disetujui 2 Agustus 2019

\begin{abstract}
ABSTRAK
Zat Pengatur Tumbuh (ZPT) merupakan senyawa organik yang dapat mengatur proses fisiologi tanaman. Penelitian ini bertujuan untuk mengkaji pengaruh komposisi media dan konsentrasi NAA serta kombinasi media dan NAA terhadap pertumbuhan lili pada tahap aklimatisasi. Penelitian dilakukan di rumah plastik di kecamatan Tembalang dan Laboratorium Fisiologi dan Pemuliaan Tanaman, Fakultas Peternakan dan Pertanian Universitas Diponegoro, Semarang. Rancangan yang digunakan dalam penelitian adalah Rancangan Acak Lengkap (RAL) Faktorial 3 x 5 dengan ulangan 3 kali. Faktor pertama adalah berbagai komposisi media tanam yaitu arang sekam dan kompos, yang terdiri dari M1 $(1: 1)$, M2 $(2: 1)$ dan M3 (3:1). Faktor kedua adalah konsentrasi NAA terdiri dari D0 (0 ppm), D1 (2,5 ppm), D2 (5 ppm), D3 (7,5 ppm), D4 (10 ppm). Analisis data menggunakan uji anova dengan taraf signifikan 5\%, jika ada perbedaan akan diuji lanjut dengan uji Duncan Multiple Range-Test (DMRT) pada taraf $\alpha=5 \%$. Hasil penelitian menunjukkan berbagai komposisi media menghasilkan umur bertunas, tinggi tanaman, panjang akar dan bobot segar yang berbeda nyata, tapi jumlah akar yang tidak berbeda nyata. Komposisi terbaik didapatkan pada arang sekam dan kompos pada perbandingan 3:1. Konsentrasi NAA menghasilkan umur bertunas, tinggi tanaman, jumlah daun, panjang akar dan bobot segar yang tidak berbeda nyata.
\end{abstract}

Kata kunci : lili, komposisi media, konsentrasi dan NAA

\begin{abstract}
ZPT are organic compounds that can regulate plant physiology. The goals of this research was to examine the effect of the composition of plant media and NAA concentration, and to know combination of plant media's composition and NAA concentration of the growth of Lilium longiflorum at the acclimatization stage. The research was carried in Tembalang, Semarang City and at the Physiology and Plant Breeding Laboratory, Faculty of Animal Husbandry and Agriculture, Diponegoro University, Semarang. The design used in the research was Factorial 3 x 5 Complete Random Design (CRD) with 3 replications. The first factor is the different of plant's media, husk charcoal and compost, consists of M1 (1:1) M2 (2:1) and M3 (3:1). The second factor is the concentration of NAA, consists of D0 (0 ppm),D1 (2,5 ppm), D2 (5 ppm), D3 (7,5 ppm) and D4 (10 ppm). Data analysis using anova test with a significance level of $5 \%$, if there are differences will be further tested with the Duncan Multiple Range-Test (DMRT) with $\alpha=5 \%$. Media's composition resulted age of germinate, plant height, long of root and vegetatife fresh weight were significantly different, but number of root are not significantly. The best composition are M3 (3:1). Concentration of NAA resulted age of germinate, plant height, long of a root and vegetatife fresh weight were not significantly different.
\end{abstract}

Keywords : Lilies, composition of plant media, concentration and NAA 


\section{PENDAHULUAN}

Tanaman lili merupakan tanaman introduksi yang berasal dari Asia Timur. Bunga ini banyak digunakan dalam acara perkawinan dan ritual keagamaan. Lili umumnya dimanfaatkan sebagai tanaman hias, terutama tanaman hias bunga potong. Harga bunga lili di pasaran relatif tinggi namun tetap diminati konsumen. Perbanyakan secara konvensional seringkali tidak dapat memenuhi permintaan lili yang semakin naik. Oleh karena itu, diperlukan metode perbanyakan yang lebih cepat seperti perbanyakan secara kultur jaringan untuk menghasilkan bibit yang banyak dan seragam dalam waktu yang singkat. Aklimatisasi merupakan salah satu tahap kultur jaringan yang sangat penting, karena tahap ini merupakan proses penyesuaian peralihan lingkungan dari kondisi heterotrof (tidak dapat membuat makanan sendiri) ke lingkungan autotrof (dapat membuat makanan sendiri).

Media tanam merupakan salah satu faktor pendukung pertumbuhan tanaman agar dapat tumbuh dengan baik. Media tanam berfungsi sebagai tempat melekat dan tempat menyimpan air yang diperlukan untuk pertumbuhan. Media tanam dengan aerasi dan drainase baik dapat merangsang pertumbuhan akar yang dapat mempengaruhi pertumbuhan bagian tanaman lainnya. Media arang sekam tidak mudah lapuk dan tidak mudah ditumbuhi cendawan dan bakteri, tetapi miskin unsur hara sehingga harus diaplikasikan pupuk untuk menunjang pertumbuhan tanaman. Campuran dua macam media dapat memperbaiki kekurangan masing-masing media tersebut, antara lain dalam pertukaran oksigen dalam ruang pori media tanam serta dalam mempertahankan kelembapan media.

Zat Pengatur Tumbuh (ZPT) atau hormon tanaman merupakan senyawa organik yang dihasilkan oleh tanaman dalam konsentrasi yang dapat mengatur proses fisiologi tanaman. Pertumbuhan planlet lili dapat dipacu dengan menambahkan ZPT dari golongan auksin secara eksogen. Auksin dapat merangsang pembelahan dan diferensiasi sel, serta sering digunakan untuk merangsang pertumbuhan khususnya perakaran, sehingga auksin dibutuhkan pada tahap aklimatisasi untuk perkembangan akar. Beberapa ZPT dari golongan auksin yaitu Indole Acetic Acid (IAA), Indole Butyric Acid (IBA) dan Napthalene Acetic Acid (NAA). IBA dan NAA lebih efektif daripada IAA, sebab keduanya lebih stabil terhadap oksidasi dan cahaya. Tujuan penelitian adalah untuk mengkaji pengaruh beberapa komposisi media dan konsentrasi NAA terhadap pertumbuhan lili pada tahap aklimatisasi.

\section{METODE PENELITIAN}

Penelitian dilaksanakan dari bulan Maret s/d Mei 2018 di rumah plastik kecamatan Tembalang dan Laboratorium Fisiologi dan Pemuliaan Tanaman, Fakultas Peternakan dan Pertanian Universitas Diponegoro, Semarang. Bahan-bahan yang akan digunakan pada penelitian ini adalah planlet tanaman lili yang didapat dari Laboratorium Pengembangan Balai Penelitian Tanaman Hias (Balithi), ZPT NAA, arang sekam, polybag berdiameter $10 \mathrm{~cm}$, kompos, aquadest, DithaneM45, pupuk gandasil D, plastik bening dan kayu untuk sungkup.

Penelitian ini disusun menggunakan Rancangan Acak Lengkap (RAL) pola faktorial $3 \mathrm{x}$ 5 dengan tiga kali ulangan. Faktor pertama adalah berbagai komposisi media tanam yaitu arang sekam dan kompos, yang terdiri dari M1 (1:1), M2 (2:1) dan M3 (3: 1). Faktor kedua yaitu dosis NAA terdiri dari D0 (0 ppm), D1 (2,5 ppm), D2 (5 ppm), D3 (7,5 ppm) dan D4 (10 ppm). Data hasil pengamatan diolah dengan. analisis ragam untuk mengetahui pengaruh perlakuan, dilanjutkan dengan pembandingan nilai tengah dengan Duncan MultipleRange Test (DMRT) pada taraf $5 \%$ untuk mengetahui perbedaan antar perlakuan.

Planlet lili dikeluarkan dengan menggunakan jari tangan. Planlet ditampung pada wadah yang berisi air bersih dan dicuci kemudian direndam dalam larutan fungsisida Dithane M-45 berkonsentrasi $2 \mathrm{~g} / \mathrm{l}$ selama 5 menit. Planlet ditiriskan pada wadah yang dilapisi dengan tisue untuk mempercepat hilangnya air yang menempel pada planlet. Planlet Lili yang sudah bersih dan kering dipangkas daun beserta akarnya. Planlet yang telah dipangkas ditimbang menggunakan timbangan analitik untuk mengetahui bobot 
segarnya. Planlet lili ditanam dalam polybag yang sudah diisi media tanam sesuai perlakuan. Setiap pot ditanam satu planlet. Semua planlet dimasukkan dalam sungkup plastik untuk menghindari kontaminasi.

Penyemprotan dengan perlakuan NAA ( 0 ; 2,5; 5; 7,5 dan $10 \mathrm{ppm}$ ) dilakukan satu minggu sekali sebanyak $3 \mathrm{ml}$ per tanaman. Pemeliharaan planlet lili meliputi penyiraman, pemupukan dan pengendalian hama jika diperlukan. Penyiraman dilakukan menggunakan hand sprayer. Pemupukan dengan gandasil D dosis $2 \mathrm{~g} / \mathrm{l}$ dilakukan satu minggu sekali menggunakan hand sprayer.

\section{HASIL DAN PEMBAHASAN}

\section{Umur Bertunas Lili}

Hasil analisis ragam menunjukkan bahwa pemberian NAA tidak memberikan pengaruh yang nyata terhadap umur bertunas pada tanaman. Komposisi media tanam yang berbeda memberikan pengaruh yang nyata pada umur bertunas tanaman lili. Interaksi antara konsentrasi NAA dan berbagai komposisi media tidak mempengaruhi umur bertunas pada tanaman lili. Umur bertunas pada tanaman lili pada berbagai komposisi media tanam dan dosis NAA yang berbeda tersaji pada Tabel 1 .

Tabel 1. Rerata Umur Bertunas (minggu) Tanaman Lili pada Beberapa Komposisi Media Tanam dan Konsentrasi NAA

\begin{tabular}{ccccccc}
\hline \multirow{2}{*}{$\begin{array}{c}\text { Komposisi } \\
\text { media }\end{array}$} & $0 \mathrm{ppm}$ & $2,5 \mathrm{ppm}$ & $5 \mathrm{ppm}$ & $7,5 \mathrm{ppm}$ & $10 \mathrm{ppm})$ & \multirow{2}{*}{ Rerata } \\
\cline { 2 - 6 } M1 (1:1) & 2,67 & 2,67 & 3,00 & 3,00 & 2,67 & $2,80^{\mathrm{a}}$ \\
M2 (2:1) & 1,67 & 1,67 & 2,33 & 1,67 & 1,67 & $1,80^{\mathrm{b}}$ \\
M3 (3:1) & 1,33 & 1,67 & 1,33 & 1,00 & 1,33 & $1,33^{\mathrm{c}}$ \\
Rerata & 1,89 & 2,00 & 2,22 & 1,89 & 1,89 & \\
\hline
\end{tabular}

Keterangan : Superskrip berbeda pada kolom rerata menunjukkan perbedaan nyata pada hasil uji DMRT pada taraf $5 \%$

Hasil penelitian menunjukkan bahwa tidak ada perbedaan pengaruh konsentrasi NAA terhadap munculnya tunas tanaman lili. Tidak adanya pengaruh konsentrasi NAA terhadap munculnya tunas tanaman lili diduga karena auksin yang diaplikasikan secara eksogen tidak mampu memicu pertumbuhan tunas tanaman lili. Pembentukan tunas tanaman dipengaruhi oleh keseimbangan hormon auksin dan sitokinin, serta hormon endogen tanaman. Campbell (2010) menyatakan bahwa auksin yang diberikan secara eksogen tidak dapat mempengaruhi pembentukan tunas, karena pembentukan tunas lebih dipengaruhi oleh adanya sitokinin endogen. Pembentukan tunas juga dipengaruhi oleh adanya keseimbangan hormon dalam tanaman, karena cara kerja hormon tidak sendiri-sendiri, melainkan saling berinteraksi. Hormon yang diaplikasikan secara eksogen akan saling berinteraksi dengan hormon endogen tanaman. Hal ini sesuai dengan pendapat Syahid dkk. (2010) yang menyatakan bahwa efektifitas hormon yang diaplikasikan secara eksogen bergantung pada konsentrasi hormon endogen dalam jaringan tanaman. Penelitian Kaviani dkk. (2015) menunjukkan bahwa pertumbuhan tunas paling optimal pada tanaman Begonia terdapat pada pengaplikasian NAA yang dikombinasikan dengan IBA. Pembentukan tunas dapat terjadi jika hormon sitokinin lebih tinggi dibandingkan auksin, sehingga pada umumnya untuk pembentukan tunas diaplikasikan hormon sitokinin. Hal ini sesuai dengan pendapat Lestari (2011) yang menyatakan bahwa stimulasi untuk pembentukan tunas digunakan ZPT sitokinin, yaitu BA atau kinetin, sedangkan untuk pembentukan akar digunakan auksin, yaitu NAA, IAA atau IBA. Penelitian Lawalata (2011) menunjukkan bahwa perlakuan sitokinin tanpa auksin menghasilkan jumlah tunas yang lebih banyak daripada perlakuan dengan auksin pada tanaman Gloxinia (Siningia speciosa). Penelitian Nqobile (2014) menunjukkan bahwa penambahan 15 ppm NAA dengan dikombinasikan 
hormon sitokinin menghasilkan tunas terbanyak pada tanaman Asparagaceae.

Komposisi media tanam yang berbeda memberikan pengaruh yang nyata pada munculnya tunas tanaman lili. Kombinasi media pada setiap perlakuan memberikan pengaruh yang berbeda. Komposisi media terbaik didapatkan pada M3 (arang sekam dan kompos 3:1), disusul dengan M2 (arang sekam dan kompos 2:1) dan M1 (arang sekam dan kompos 1:1) menghasilkan umur bertunas yang paling lama. Komposisi M3 dapat memunculkan tunas tanaman paling cepat. Hal ini diduga karena media tanam M3 mengandung arang sekam dengan komposisi paling tinggi dibandingkan dengan media M2 dan M1, dimana struktur dari arang sekam yang memiliki lebih banyak pori-pori memiliki aerasi (pertukaran udara dalam media tanam) dan drainase (pembuangan massa air yang berlebih pada media tanam) yang bagus, memudahkan perakaran untuk menyerap air dan zat hara yang mengakibatkan kecepatan pertumbuhan tanaman termasuk munculnya tunas. Media tanam dengan komposisi kompos lebih banyak tidak menghasilkan pertumbuhan yang bagus, karena struktur kompos yang lebih padat jika terkena air dan memiliki daya evaporasi yang rendah. Penambahan media arang sekam dalam konposisi lebih banyak menjadikan media tanam memiliki banyak rongga. Hal ini didukung oleh pendapat Kusmarwiyah dan Erni (2011) yang menyatakan bahwa media tanam dengan penambahan arang sekam dapat memperbaiki porositas media sehingga baik untuk respirasi akar dan dapat mempertahankan kelembaban tanah. Arang sekam yang ditambahkan ke dalam media tanam akan dapat mengikat air, kemudian dilepaskan ke pori mikro untuk diserap oleh tanaman dan mendorong pertumbuhan mikroorganisme yang berguna bagi tanah dan tanaman. Hal ini diperkuat oleh Andriani dan Pramushinta (2017) yang menyatakan bahwa arang sekam memiliki banyak rongga yang dapat mempengaruhi drainase dan aerasi.

\section{Tinggi Tanaman Lili}

Hasil analisis ragam menunjukkan bahwa tidak adanya pengaruh interaksi antara komposisi media dan konsentrasi NAA. NAA tidak memberikan pengaruh yang nyata terhadap tinggi tanaman. Komposisi media tanam yang berbeda memberikan pengaruh yang nyata pada tinggi tanaman lili. Hasil uji DMRT tinggi tanaman di sajikan pada Tabel 2.

Tabel 2. Rerata Tinggi Tanaman Lili $(\mathrm{cm})$ pada Beberapa Komposisi Media Tanam dan Konsentrasi NAA

\begin{tabular}{ccccccc}
\hline Komposisi & \multicolumn{5}{c}{ Konsentrasi NAA } & \multirow{2}{*}{ Rerata } \\
\cline { 2 - 6 } media & $0 \mathrm{ppm}$ & $2,5 \mathrm{ppm}$ & $5 \mathrm{ppm}$ & $7,5 \mathrm{ppm}$ & $10 \mathrm{ppm}$ & \\
\hline M1 (1:1) & 1,63 & 1,53 & 1,57 & 1,17 & 2,37 & $1,65^{\mathrm{c}}$ \\
M2 (2:1) & 2,40 & 3,53 & 3,17 & 3,30 & 2,17 & $2,91^{\mathrm{b}}$ \\
M3 (3:1) & 6,43 & 4,60 & 5,83 & 4,60 & 5,47 & $5,39^{\mathrm{a}}$ \\
Rerata & 3,49 & 3,22 & 3,52 & 3,02 & 3,33 & \\
\hline
\end{tabular}

Keterangan : Superskrip berbeda pada kolom rerata menunjukkan perbedaan nyata pada hasil uji DMRT pada taraf $5 \%$

Hasil penelitian menunjukkan bahwa konsentrasi NAA tidak berpengaruh terhadap tinggi tanaman lili. Konsentrasi NAA tidak dapat meningkatkan atau menurunkan tinggi tanaman. Pertumbuhan tinggi tanaman berkaitan dengan penyerapan hara dan air melalui perakaran. Jika penyerapan hara oleh akar berlangsung dengan baik, maka pertumbuhan tanaman menjadi lebih cepat. Pengaplikasian auksin secara eksogen menggunakan sprayer diduga kurang efektif untuk menunjang pertumbuhan akar tanaman lili. Cara yang diduga efektif dalam menggunakan ZPT adalah dengan cara perendaman. Hasil penelitian Karyanti dkk. (2016) menunjukkan bahwa perlakuan ZPT dengan perendaman selama 1 jam pada kultur ex vitro bibit sagu (Metroxylon sagu 
Rottb.) menghasilkan pertumbuhan tinggi tanaman yang berbeda nyata. Perendaman memungkinkan benih mengalami imbibisi sehingga kadar air benih setelah perendaman akan meningkat dan merangsang perkecambahan atau pertunasan yang akan meningkatkan pertumbuhan tanaman. Hasil penelitian Yusnita dkk. (2016) menunjukkan bahwa pengaplikasian larutan NAA dengan cara perendaman selama satu jam pada tunas kelapa sawit memberikan keberhasilan aklimatisasi sebesar 60\%, terjadi pembentukan dan pemanjangan akar dan terjadi penambahan daun muda sebanyak 1-2 helai dari setiap benih yang ditanam.

Komposisi media tanam yang berbeda memberikan pengaruh yang nyata pada tinggi tanaman Lili. Komposisi media terbaik didapatkan pada M3 yaitu arang sekam dan kompos (3:1), disusul dengan M2 dengan perbandingan 2:1. Media M1 dapat menurunkan tinggi tanaman. Media M3 dapat menghasilkan tinggi tanaman paling baik. Media M3 dapat menghasilkan tinggi tanaman paling baik, diduga karena media tersebut mengandung komposisi arang sekam paling tinggi dibandingkan dengan media lainnya. Struktur dari arang sekam yang memiliki lebih banyak pori-pori memiliki aerasi dan drainase yang bagus, memudahkan perakaran untuk menyerap zat hara yang mengakibatkan kecepatan pertumbuhan tanaman, yang akan meningkatkan pertumbuhan tinggi tanaman. Arang sekam sangat potensial untuk digunakan sebagai media tanam alternatif yang memiliki beberapa kelebihan, yaitu memiliki struktur yang dapat menjaga keseimbangan aerasi, memiliki sifat remah sehingga udara, air dan akar dapat mudah masuk kedalam fraksi tanah. Karakteristik tersebut sesuai dengan media yang dibutuhkan untuk pertumbuhan tanaman lili, yaitu harus porous, tidak terlalu lembab dan memiliki aerasi dan drainase yang baik (Dinas Pertanian, 2014). Media M1 merupakan komposisi media yang paling kaya akan bahan organik (arang sekam dan kompos 1:1). Namun, media ini menghasilkan tinggi yang paling rendah. Hal ini diduga karena tanaman lili merupakan tanaman yang berumbi, sehingga dapat menyimpan cadangan makanannya di umbi yang akan digunakan untuk pertumbuhan tanaman, dari pada menyerap bahan organik dari kompos. Umbi sudah terbentuk pada awal penanaman, karena sebelumnya planlet sudah ditumbuhkan pada media agar. Berbeda dengan tanaman lainnya, lili pada tahap aklimatisasi tidak memerlukan terlalu banyak sumber hara dari media tanam. Slamet (2011) menyatakan bahwa setiap jenis tanaman menghendaki komposisi media dan perlakuan yang berbeda untuk memperoleh hasil aklimatisasi yang baik.

\section{Jumlah dan Panjang Akar Lili}

Hasil analisis ragam menunjukkan bahwa interaksi antara konsentrasi NAA dan berbagai komposisi media tidak mempengaruhi jumlah dan panjang akar pada tanaman lili. NAA tidak memberikan pengaruh yang nyata terhadap jumlah dan panjang akar. Komposisi media tanam yang berbeda tidak memberikan pengaruh yang nyata pada munculnya akar tanaman lili, namun berbeda nyata pada panjang akar. Jumlah dan panjang akar pada tanaman Lili pada konsentrasi NAA dan komposisi media yang berbeda tersaji pada Tabel 3 .

Hasil penelitian menunjukkan bahwa tidak ada perbedaan dengan pemberian NAA pada berbagai dosis terhadap jumlah akar tanaman lili. Komposisi media yang berbeda tidak mempengaruhi pertambahan jumlah akar tanaman lili. Hal ini diduga karena perakaran dapat ditumbuhkan dengan menggunakna perangsang berupa hormon dengan dosis yang tepat. NAA sendiri merupakan ZPT yang dapat memacu perakaran, karena ZPT ini berfungsi pada tahap diferensiasi dan pembelahan sel pada ujung meristem akar. Hal ini sesuai dengan pendapat Widiastoety (2014) yang menyatakan bahwa auksin yang lebih tinggi dibandingkan sitokinin akan menyebabkan diferensiasi mengarah ke pertumbuhan akar yang disebabkan terjadinya proses pembelahan sel pada meristem ujung akar. Tanaman memerlukan auksin dalam konsentrasi tertentu agar dapat memacu pertambahan jumlah akar. Tidak adanya pengaruh NAA pada pertambahan jumlah akar tanaman lili diduga karena konsentrasi auksin yang diberikan kurang tinggi sehingga tidak dapat memacu pertumbuhan jumlah akar tanaman lili. 
Hasil penelitian menunjukkan pemberian NAA tidak memberikan pengaruh yang nyata terhadap panjang akar pada tanaman. Komposisi media tanam yang berbeda memberikan pengaruh yang nyata terhadap panjang akar tanaman. Interaksi antara konsentrasi NAA dan berbagai komposisi media tidak mempengaruhi panjang akar pada tanaman. Pemberian NAA yang tidak berpengaruh terhadap panjang akar diduga karena metode pemberian NAA dengan cara penyemprotan dinilai kurang efektif untuk memacu pertumbuhan akar. Penyemprotan NAA yang dilakukan diduga tidak terserap maksimal oleh daerah perakaran tanaman. Hasil penelitian Budianto dkk. (2013) bahwa perlakuan perendaman berpengaruh sangat nyata pada rata-rata panjang akar sirih merah.

Komposisi media yang berbeda berpengaruh nyata terhadap pertambahan panjang akar tanaman. Pemberian arang sekam lebih banyak akan meningkatkan panjang perakaran. Media M3 merupakan komposisi yang paling baik untuk meningkatkan perakaran tanaman. Hal ini diduga karena pemberian arang sekam yang lebih banyak akan membentuk pori lebih luas sehingga baik untuk pertumbuhan panjang akar. Selain itu, komposisi dari kompos yang sesuai juga mempengaruhi pertumbuhan tanaman lili karena menyokong zat hara yang dibutuhkan untuk pertumbuhannya Salah satu keuntungan menggunakan bahan organik seperti arang sekam sebagai media tanam adalah memiliki struktur yang dapat menjaga keseimbangan aerasi. Arang sekam mempunyai sifat remah sehingga udara, air, dan akar mudah masuk dalam fraksi tanah dan dapat mengikat air. Hal ini sangat penting bagi akar bibit tanaman karena media tumbuh sangat berkaitan dengan pertumbuhan akar atau sifat di perakaran tanaman. Agustin dkk. (2014) menyatakan bahwa karakteristik arang sekam padi adalah memiliki sifat lebih remah dibanding media tanam lainnya. Sifat inilah yang diduga memudahkan akar tanaman dapat menembus media dan daerah pemanjangan akar akan semakin besar serta dapat mempercepat perkembangan akar. Hal ini didukung oleh pendapat Sofyan dkk. (2014) yang menyatakan bahwa arang sekam memiliki kandungan karbon, sulfur dan fosfor yang berfungsi mempercepat pertumbuhan akar dan tinggi tanaman.

Tabel 3. Rerata Jumlah dan Panjang (cm) Akar Tanaman Lili pada Beberapa Komposisi Media Tanam dan Konsentrasi NAA

\begin{tabular}{|c|c|c|c|c|c|c|}
\hline \multirow{2}{*}{$\begin{array}{c}\text { Komposisi } \\
\text { media }\end{array}$} & \multicolumn{5}{|c|}{ Konsentrasi NAA } & \multirow{2}{*}{ Rerata } \\
\hline & $0 \mathrm{ppm}$ & $2,5 \mathrm{ppm}$ & $5 \mathrm{ppm}$ & $7,5 \mathrm{ppm}$ & $10 \mathrm{ppm}$ & \\
\hline & \multicolumn{6}{|c|}{--------------------------jumlah akar------------------ } \\
\hline M1 (1:1) & 0,67 & 1,00 & 1,33 & 0,33 & 1,33 & 0,93 \\
\hline M2 (2:1) & 0,67 & 0,67 & 0,67 & 1,00 & 1,00 & 0,80 \\
\hline M3 (3:1) & 1,00 & 0,67 & 1,00 & 1,33 & 1,00 & 1,00 \\
\hline \multirow[t]{2}{*}{ Rerata } & 0,78 & 0,78 & 1,00 & 0,89 & 1,11 & \\
\hline & \multicolumn{6}{|c|}{--Panjang akar (cm)-------------- } \\
\hline M1 (1:1) & 0,10 & 0,23 & 0,16 & 0,30 & 0,36 & $0,23^{\mathrm{b}}$ \\
\hline M2 (2:1) & 0,23 & 0,30 & 0,33 & 0,30 & 0,36 & $0,30^{\mathrm{ab}}$ \\
\hline M3 (3:1) & 0,33 & 0,20 & 0,46 & 0,46 & 0,46 & $0,38^{\mathrm{a}}$ \\
\hline Rerata & 0,22 & 0,24 & 0,32 & 0,35 & 0,39 & \\
\hline
\end{tabular}

Keterangan : Superskrip berbeda pada kolom rerata menunjukkan perbedaan nyata pada hasil uji DMRT pada taraf $5 \%$

\section{Bobot Segar Lili}

Hasil analisis ragam menunjukkan bahwa interaksi antara konsentrasi NAA dan berbagai komposisi media tidak mempengaruhi bobot segar pada tanaman. Pemberian NAA tidak memberikan pengaruh yang nyata terhadap bobot segar pada tanaman. Komposisi media tanam yang berbeda 
memberikan pengaruh yang nyata pada bobot segar tanaman. Bobot segar tanaman Lili pada konsentrasi NAA dan komposisi media yang berbeda tersaji pada Tabel 4 .

Hasil penelitian menunjukkan bahwa NAA tidak memberikan pengaruh yang nyata terhadap bobot segar tanaman. Hal ini diduga karena pengaplikasian NAA secara eksogen menggunakan sprayer tidak mampu memicu pertumbuhan tanaman, sehingga tidak berdampak pada pertambahan bobot segarnya. Metode perendaman diduga lebih efektif untuk memicu pertumbuhan tanaman sehingga akan menambah bobot segarnya.
Perendaman NAA akan meningkatkan pertumbuhan perakaran tanaman dan diferensiasi sel. Perakaran yang tumbuh baik akan mengoptimalkan transportasi zat hara dari akar ke tubuh tanaman, sehingga secara tidak langsung akan menambah bobot segarnya. Hasil penelitian Lewis dkk. (2011) menunjukkan bahwa pengaplikasian auksin meningkatkan akar lateral pada tanaman. Penelitian Abdul Malik dkk. (2012) menunjukkan bahwa penambahan 1 ppm NAA mampu meningkatkan jumlah akar pada subkultur tanaman Arachis hypogea $\mathrm{L}$.

Tabel 4. Rerata Bobot Segar (g) Tanaman Lili pada Berbagai Komposisi Media dan Konsentrasi NAA

\begin{tabular}{ccccccc}
\hline \multirow{2}{*}{$\begin{array}{c}\text { Komposisi } \\
\text { media }\end{array}$} & $0 \mathrm{ppm}$ & $2,5 \mathrm{ppm}$ & $5 \mathrm{ppm}$ & $7,5 \mathrm{ppm}$ & $10 \mathrm{ppm}$ & \multirow{2}{*}{ Rerata } \\
\cline { 2 - 6 } M1 (1:1) & 0,08 & 0,17 & 0,11 & 0,08 & 0,13 & $0,11^{\mathrm{c}}$ \\
M2 (2:1) & 0,14 & 0,17 & 0,17 & 0,16 & 0,16 & $0,16^{\mathrm{b}}$ \\
M3 (3:1) & 0,23 & 0,18 & 0,17 & 0,18 & 0,19 & $0,19^{\mathrm{a}}$ \\
Rerata & 0,15 & 0,17 & 0,15 & 0,14 & 0,16 & \\
\hline
\end{tabular}

Keterangan : Superskrip berbeda pada kolom rerata menunjukkan perbedaan nyata pada hasil uji DMRT pada taraf $5 \%$

Perbedaan komposisi media berpengaruh nyata terhadap bobot segar tanaman. Pemberian kompos dengan komposisi yang sesuai dan tidak berlebihan akan mendorong pertumbuhan tanaman lili. Komposisi dari kompos yang terlalu banyak memungkinkan media tanam menjadi padat dan terlalu lembab, sehingga hal ini akan menyulitkan aktivitas perakaran tanaman. Media terbaik yang dapat meningkatkan bobot segarnya yaitu arang sekam dan kompos dengan perbandingan 3 :1. Penambahan arang sekam yang lebih banyak dapat meningkatkan bobot segar tanaman. Hal ini karena media arang sekam yang memiliki banyak rongga memudahkan pertumbuhan perakaran tanaman yang akan meningkatkan pertumbuhan secara keseluruhan pada tanaman lili, termasuk pertambahan bobotnya. Selain itu, arang sekam mampu mengikat air sehingga dapat diserap tanaman yang akan mempertahankan bobot segarnya. Kusmarwiyah dan Erni (2011) menyatakan bahwa arang sekam yang ditambahkan ke dalam media tanam akan dapat mengikat air, kemudian dilepaskan ke pori mikro untuk diserap oleh tanaman dan mendorong pertumbuhan mikroorganisme yang berguna bagi tanah dan tanaman. Hasil penelitian Andriani dan Pramushinta (2017) menyatakan bahwa perlakuan media arang sekam menghasilkan berat tanaman paling besar terhadap respon fisiologis anggrek Cattleya pada tahap aklimatisasi, diduga karena arang sekam memiliki banyak rongga yang dapat mempengaruhi drainase dan aerasi.

\section{KESIMPULAN}

Kesimpulan dari penelitian ini adalah terdapat pengaruh komposisi media tanam, tidak ada pengaruh dosis NAA dan interaksinya dengan komposisi media tanam terhadap pertumbuhan tanaman lili. Komposisi media tanam terbaik untuk mendukung pertumbuhan tanaman lili fase aklimatisasi adalah media tanam arang sekam dan kompos dengan perbandingan $3: 1$. . 


\section{DAFTAR PUSTAKA}

Abdul Malik,M.M., Usman, M.M., Olarewaju, J.D. and Aba, D.A. 2012. Effect of Napthalene Acetic Acid (NAA) on in vitro rooting of regenerated microshoots of groundnut (Arachis hypogea L.). Bayero Journal of Pure and Applied Sciences 5 (2) : 128-131.

Agustin, D., Riniarti, M. dan Duryat. 2014. Pemanfaatan limbah serbuk gergaji dan arang sekam sebagai media sapih untuk cempaka kuning (Michelia champaca). J. Sylva Lestari 2 (3) : 49-58.

Andriani, V dan Pramushinta, I. 2017. Pengaruh media tanam terhadap respon fisiologi aklimatisasi anggrek Cattleya. Journal of Science 9 (2) : 17-19.

Budianto,E., Badami, K dan Arsyadmunir, A, 2013. Pengaruh kombinasi macam ZPT dengan lama perendaman yang berbeda terhadap keberhasilan pembibitan sirih merah (Piper crocatum Ruiz \& Pav) secara stek 3 (2) : 103 111.

Campbell, N.A. 2010. Biologi. Penerbit Erlangga, Jakarta

Dinas Pertanian Tanaman Pangan. 2014. Pengembangan Tanaman Hias, Sumatra Barat.

Karyanti., Sigit, Y., Tajuddin, T., Erwinda., Minaldi dan Haska, N. 2016. Penanganan anakan muda pada kultur ex vitro untuk menghasilkan bibit sagu (Metroxylon sagu Rottb.) siap tanam. J. Bioteknol biosans Indonesia 3 (1) : 13-19.

Kaviani, B., Hashemabadi, D., Khodabbash, H., Onsinejad, R., Ansari, M.H. and Haghighat, N. 2015. Micropropagation of Begonia rex. Putz. By 6-Benzyladeninand $\alpha$ - Napthalene acetic acid. International Journal of Bioscience (IJB) 6 (5) : P. 8-15.

Kusmarwiyah, R dan Erni S. 2011. Pengaruh media tumbuh dan pupuk organik cair terhadap pertumbuhan dan hasil tanaman seledri (Apium graveolens L.) J. Crop Agro 4 (2): 7 12.
Lawalata, I.J. 2011. Pemberian beberapa kombinasi ZPT terhadap regenerasi tanaman Gloxinia (Siningia speciosa) dari eksplan batang dan daun secara in vitro. J. Exp. Life. Sci 1 (2) : 83-87.

Lestari, E.G. 2011. Peranan Zat Pengatur Tumbuh (ZPT) dalam Perbanyakan Tanaman Melalui Kultur Jaringan. J. Agro Biogen 7 (1) : 63-68.

Lewis, D.R., Negi, S., Sukumar, P. And Muday, G.K. 2011. Ethylene inhibits lateral root development, increases IAA transport and expression of PIN 3 and PIN 7 auxin efflux carriers. Development 138 : 3485-3495.

Nqobile, A., Masondo,. Adeyemi, O., Aremu., Jeffrey, F.F. and Staden, J.V. 2014. Plant growth regulator induced phytochemical and antioxidant variations in micropropagated and acclimatized Eucomis autumnalis subspecies autumnalis (Asparagaceae). Journal of Plant Pathology 36. pp 2467-2479.

Slamet. 2011. Perkembangan teknik aklimatisasi tanaman kedelai hasil regenerasi kultur in vitro. J. Litbang Penelitian 30 (2) : 48-54.

Sofyan, S., Riniarti, M dan Duryat. 2014. Pemanfaatan limbah teh, sekam padi, dan arang sekam sebagai media tumbuh bibit trembesi (Samanea saman). J. Sylvia Lestari $2(2): 61-70$.

Syahid, S.F., Kristina, N.N. dan Seswita, D. 2010. Pengaruh komposisi media terhadap petumbuhan kalus dan kadar tannin dari daun jati belanda (Guazuma ulmifolia Lamk.) secara in vitro. J. Littri 16 (1): 1-5.

Widiastoety, D. 2014. Pengaruh auksin dan sitokinin terhadap pertumbuhan planlet anggrek Mokara. J. hort 24 (3) 230-238.

Yusnita, R., Mariska, I., Purnamaningsih, R., Lestari, E dan Utami, S. 2016. Induksi akar tunas kelapa sawit (Elaeis guineensis Jacq.) secara in vitro dan ex vitro. J. Littri 22 (1) :37-42. 